УДК 94(410).07

\title{
ОБРАЗОВАТЕЛЬНАЯ ПОЛИТИКА И ФОРМИРОВАНИЕ БРИТАНСКОЙ ИДЕНТИЧНОСТИ НА НАЦИОНАЛЬНЫХ ОКРАИНАХ
}

\author{
(c) 2021 С.Г. Малкин \\ Самарский государственный социально-педагогический университет
}

Статья поступила в редакцию 19.10.2021

\begin{abstract}
Обращение к историческим кейсам имеет не только академическое, но и политическое значение, особенно в тех случаях, когда актуальная повестка во многом определяется риторикой и опытом конфликтов, уходящих корнями в историю. В этой связи основное внимание в статье уделено характеру, формам и последствиям образовательной политики Великобритании на национальных окраинах в эпоху Нового времени в процессе формирования британской идентичности, поддерживавшей на идеологическом уровне практики национально-государственного строительства как в рамках Соединенного Королевства, так и в пределах Британской империи. На конкретных исторических и современных примерах показаны возможности и ограничения образовательной политики как гуманитарной технологии укрепления идеологической и риторической основ Великобритании в качестве многонационального и сложносоставного государственного образования. В фокусе исследования - исторически наиболее укорененный в этом смысле шотландский пример, анализ которого позволяет более предметно рассмотреть связь образовательных стратегий властей в прошлом и их последствий в настоящем, имея в виду перспективы повторного референдума о независимости Шотландии на фоне выхода Великобритании из Европейского союза.

Ключевые слова: образовательная политика, британская идентичность, национальные окраины; Великобритания, Ирландия, Шотландия.
\end{abstract}

DOI: $10.37313 / 2658-4816-2021-3-4-66-71$

\section{Работа подготовлена в рамках проекта № 073-00065-21-01 от 14.07.2021 государственного задания Министерства просвещения РФ}

Современная западная (в первую очередь англо-американская) теория и опирающаяся на нее практика антиповстанчества подходят к школьному обучению как к одному из важнейших элементов политики «завоевания сердец и умов» местного населения. В этом смысле их идейная генеалогия восходит к установкам военных и гражданских офицеров колониальных служб европейских империй на завершающем этапе их существования, ознаменовавшимся началом деколонизации (в ограниченном масштабе до середины XX в.) после

$\overline{\text { Малкин Станислав Геннадьевич, доктор историче- }}$ ских наук, заведующий кафедрой всеобщей истории, права иметодики обучения.E-mail:s.g.malkin@mail.ru
Великой войны. Британский случай при этом является одним из наиболее показательных в этом вопросе. В этой связи эксперты довольно часто обращают внимание на особенности гражданского образования в школах Северной Ирландии в настоящее время. Власти рассматривают его как один из важных способов нормализации ситуации в провинции, расколотой по этнорелигиозному признаку и на протяжении десятилетий охваченной беспорядками, сопряженными с актами политического насилия (1968-1998 гг.) .

Предполагается, что такая образовательная модель должна способствовать формированию и укреплению общей оль- 
стерской идентичности на региональной основе. Однако этот опыт показывает: дети из католических и протестантских районов и округов в Ольстере по-прежнему обучаются раздельно (93\% обучающихся), что многое говорит об отдаленности перспектив этой образовательной модели с точки зрения формирования североирландской идентичности, особенно после «неожиданного» обострения вопроса о статусе этой провинции в связи с недавним выходом Великобритании из Европейского союза ${ }^{2}$. $\mathrm{He}-$ прекращающийся приток рекрутов в террористические организации в провинции, как в католические, так и в протестантские, за счет подрастающего поколения и после Соглашения Страстной пятницы (1998 г.), призванного положить конец противостоянию британских сил безопасности и Временной Ирландской республиканской армии, также оставляет вопросы относительно степени эффективности в том числе и образовательного трека в рамках мирного процесса в $\mathrm{Ce}$ верной Ирландии.

При этом речь идет о стране с давним и разнообразным, хотя и не всегда успешным опытом инклюзивного образования, накопленным на фоне деколонизации, способствовавшей наплыву подданных Короны из бывших британских колоний в метрополию, начиная с середины XX в. В этом смысле сохранение политического значения гражданского образования, потенциала его реализации в зонах современных локальных конфликтов актуализирует разговор о гуманитарных технологиях и образовательных стратегиях в формировании национальной идентичности. Более того, исторически регулирование образовательной сферы в принципе являлось одной из важнейших составляющих колониальной и окраинной политики европейских держав по укреплению лояльности местных подданных Короны не только на закате, но и в эпоху строительства первых глобальных империй.

В отличие от североирландского случая, имеющего обширную историографию и уже давно превратившегося в своеобразную фигуру речи, шотландский пример оказался куда более успешен (как образовательный и политический проект) и по этой причине заслуживает пристального внимания. $\mathrm{K}$ тому же долгосрочные последствия Брекзита, как стали называть выход Великобритании из Европейского союза, сказались не только на перспективах мирного процесса в Ольстере и связанных с ним инициатив, в том числе и в образовательной сфере. В полный рост встал вопрос о дальнейшем пребывании Шотландии в составе Соединенного Королевства и, следовательно, о существовании самой Великобритании как таковой. Если на референдуме 2014 г. о независимости Шотландии с незначительным перевесом все же победили сторонники сохранения союза с Англией, то после решения Лондона о выходе из Европейского союза проведение повторного референдума о независимости вновь вошло в актуальную политическую повестку Шотландии - и вновь усилиями правящей Шотландской национальной партии.

Конечно, процесс деволюции - передачи значительной части законодательных полномочий на места - в Великобритании был запущен еще во второй половине XX в. B частности, шотландский парламент был восстановлен в 1997 г. Однако в целом пребывание Шотландии в составе Великобритании, фактически - с унии корон в 1603 г., юридически - с парламентской унии 1707 г., можно охарактеризовать как долгосрочный пример взаимовыгодного сотрудничества. Мир и стабильность на окраинах Великобритании утверждались не только с помощью королевской армии, но и благодаря расширению в местной среде круга сторонников британского мира - в политическом и культурном смысле слова. Фактически речь шла о формировании новой британской идентичности, основанной не на этническом происхождении, а на общих политических и экономических приоритетах и ценностях. Этот процесс был запущен вместе с унией парламентов в 1707 г. и про- 
должался на протяжении всей последующей истории Британской империи, вплоть до середины XX в. Ее строительство при этом также являлось частью проекта формирования британской национальной идентичности (в гражданском смысле слова, учитывая ее многонациональный состав), отражавшего, в свою очередь, процесс формирования британской политической нации.

При этом особых результатов по интеграции Горной Шотландии власти добились в рамках образовательной политики, имевшей языковую и дискурсивную стороны. Еще в начале XVII в. корона продемонстрировала ясное понимание возможностей образования в вопросах культурной и политической интеграции горцев Шотландии: «Невежество и грубость [горцев] вызваны пренебрежением... образованием... Средство [к исправлению сложившегося положения заключается] в том, что каждый джентльмен или йомен в указанных землях, или другой, имеющий детей [и обладающий определенным состоянием], должен отправлять своего старшего сына или, если нет сыновей, то старшую дочь в школы Лоуленда [Нижней Шотландии]...для обучения разговору и чтению на английском языке»4.

Однако революционные события, наполнившие в истории Англии и Шотландии почти весь XVII в., прервали и без того трудно реализуемую в условиях лишь номинально подконтрольного короне Хайленда образовательную политику первых Стюартов. Новые правители столкнулись с той же проблемой - политической и культурной обособленностью Горной Страны. Якобитское движение (за возвращение короны «трех королевств» дому Стюартов), нашедшее широкую поддержку в Хайленде, требовало от новых правителей возобновления активных мер в этом крае. Вильгельм Оранский был более занят политической игрой на континенте, предпочитая в отношении горцев Шотландии показательные репрессии и подкуп вождей 5 . Тем же в целом ограничивалась его преемница королева Анна, и даже после принятия короны более деятельными в Горной Шотландии представителями дома Ганноверов стратегия образования и ее языковые практики в Горной Стране все еще оставались в ведении Церкви Шотландии ${ }^{6}$.

Прозелитизм приходских школ в Горной Шотландии к началу XVIII столетия может быть описан в тех же терминах, что и деятельность школ Нижней Шотландии по обучению горцев в начале XVII в.: пример межкультурного образования на периферии привычного Соединенному Королевству жизненного уклада. Протестантизм к началу XVIII в. стал одной из важнейших основ британской идентичности в Англии и Шотландии, вновь гонимый после Славной революции католицизм прочно ассоциировался с якобитами. Наиболее последовательными сторонниками Стюартов в их попытках вернуть шотландской династии британский престол были именно горцы, многие из которых оставались католиками или сторонниками епископата. Борьба за распространение протестантизма в Хайленде характеризовалась поэтому как борьба за «освобождение от варварства и папизма» и превращение жителей Горной Страны в лояльных протестантской же монархии британцев ${ }^{7}$.

Такое просвещение Горной Шотландии на практике, однако, не шло проторенным путем, а пробивало себе путь сквозь череду социокультурных экспериментов. Первые из них были связаны с попыткой властей использовать в привнесенном образовании местный, гэльский язык. Последующие характеризовались сочетанием в преподавании английского языка и протестантского образовательного дискурса, также бывшего для Горной Страны в данный период явлением во многом внешним. Первые преобразования пришлись на 1690-е гг. Тайный Совет Шотландии уже в 1690 г. выделил 1 тыс. шотландских фунтов (для дефицитной казны Шотландского королевства в тот период немалая сумма) на распространение в Хайленде Библий на гэльском языке ${ }^{8}$. Вместе с недостатком 
церковной протестантской литературы на гэльском остро ощущалась нехватка проповедников, знавших гэльский язык и способных выступать связующим звеном между противоречивыми культурами. В 1698 г. Ассамблея Шотландской Церкви решила отбирать среди обучавшихся горских юношей наиболее способных с тем, чтобы пополнить редкие ряды преподавателей приходских школ, знавших гэльский язык 9

Разбойная деятельность якобитов в Горной Стране и сохранение пограничных практик насильственного характера на рубежах Горной Страны с одной стороны, и религиозное рвение протестантской общины Шотландии, с другой, вызвали к жизни иной, более масштабный по размаху и результатам опыт межкультурного общения через просвещение в Горной Шотландии. В 1698 г. было образовано тесно связанное с Церковью Шотландии «Общество пропаганды христианского знания». Оно сразу же обозначило свое негативное отношение к гэльскому языку как главному препятствию в распространении протестантской религии (в Соединенном Королевстве понимавшейся именно как британский культурный код). Учителя приходских школ в Хайленде по-прежнему в основном не знали гэльский язык, местные уроженцы порой в такой же степени были знакомы с английским, и тем не менее амбициозная образовательная политика «Общества» дала в формировании британской идентичности свои результаты.

В 1720-1730-е гг. Горная Страна подверглась настоящему культурному вторжению новой британской традиции. Вслед за военными дорогами и фортами следовало, конечно, и «Общество пропаганды христианского знания», а вместе с ним - английский язык и протестантское вероисповедание - одни из самых важных основ британских общественных институтов в тот период как в Англии, так и в Шотландии. Показателен пример горной области Рэннох, об «отсутствии цивилизации и варварстве» в которой к началу XVIII в. сообщают современники, очевидно вы- ступавшие за распространение в Хайленде британского мира. Первые основанные «Обществом» школы с преподаванием на английском здесь - первые межкультурные контактные зоны в крае - появились в 1732 г. К 1765 г. их насчитывалась дюжина со средним количеством учеников в 60 - 65 человек, что для такой отдаленной области и по меркам Горной Страны, чье население в 1747 г. не превышало 230 тыс. человек, являлось заметным ${ }^{10}$. В 1719 г. «Обществом» основано 49 школ в Хайленде, к 1732 г. их число было доведено до 109 и 200 к концу XVIII в. ${ }^{11}$

Кросскультурное образование в Горной Шотландии в первой половине XVIII в. ждали и определенные трудности. Труднодоступность Горного Края, сложная военнополитическая и криминогенная обстановка в крае приводили к тому, что, например, МакДоналды из Мойдэрта и в 1755 г. говорили на гэльском языке и у них не было ни одной школы с преподаванием на английском $^{12}$. Не понимая и потому в том числе не принимая своих южных соседей, эти МакДоналды и в последнем якобитском восстании 1745 - 1746 гг. продолжали держать сторону Стюартов ${ }^{13}$.

Вместе с тем по ту сторону горских палашей и гренадерских штыков очаги британской культуры успели пустить в неподатливую местную почву крепкие корни. Вторгаясь в чужую культурно-историческую систему, Лондон не мог (и потому не собирался) в одночасье изменить традиции, укоренившиеся в Горной Шотландии. Однако его проводники в Горной Стране решительно обозначали и утверждали в крае новые границы британской культуры, расширяли для нее проницаемость Хайленда - дороги, военные форты и школы с учителями-протестантами и преподаванием на английском языке ускоряли передвижение не только стражей порядка в Горной Шотландии, но и традиций созидавшейся Великобритании. Принятие британской идентичности, которая вполне сочеталась с шотландской, открывало перед горцами 
наряду с временным давлением на традиционные язык и культуру (до конца XVIII в.) возможности быстрого карьерного роста и в королевской армии, и в торговых домах, и даже при королевском дворе ${ }^{15}$. C 1792-го по 1815 г. - время кульминации почти векового изнурительного противостояния «Великой Британии» и «Великой Франции» - почти каждый четвертый житель Хайленда проходил добровольную службу в полках под флагом Соединенного Королевства ${ }^{14}$.

Разные исторические судьбы Ирландии и Шотландии с точки зрения истории их отношений с Англией, безусловно, повлияли на характер ирландской и шотландской национальной идентичностей и степень их комплементарности британской идентичности. В результате Ирландия (за исключением шести северо-восточных протестантских графств Ольстера) фактически добилась независимости от Лондона еще в начале XX в., в 1921 г., после двух лет партизанской войны, а окончательно выйдет из-под власти короны в 1937 г. Шотландия и в первой трети XXI в. по-прежнему является частью Соединенного Королевства, несмотря на неприятие Брекзита большей частью шотландцев и обещание Шотландской национальной партии повторить референдум о независимости 2014 г. Таким образом, образовательная политика Лондона на этих национальных окраинах выступала и выступает не только как инструмент формирования британской идентичности, но и маркер эффективности этого процесса. В этом смысле ирландский и шотландский случаи представляют особый интерес, являясь идеальной парой для сравнительно-исторического анализа. Такой подход, в свою очередь, позволяет переосмыслить роль гуманитарных технологий как в прошлом, так и на современном этапе национально-государственного строительства, однако это предмет отдельного разговора, обсуждение которого выходит за рамки данной статьи.

\section{ПРИМЕЧАНИЯ}

${ }^{1}$ Подробнее об этой образовательной модели: Фахретдинова А.П., Абакумова О.А. Различные подходы к гражданскому образованию в Великобритании // Вестник ТГПУ. 2017. 14 (181). C. $128-132$.

${ }^{2}$ Edwards A., McGrattan C. Ireland, 2021: a century of insurgency, terrorism and security challenges // Small Wars \& Insurgencies. 2021. Vol. 32. Issue 4 - 5. Р. 587 - 597. Подробнее об образовательных практиках в Ольстере см., например: Michaels J.H. An education in counterinsurgency // International Political Review. 2020. Issue 8. P. 11 - 20; Hynd S. Small Warriors? Children and Youth in Colonial Insurgencies and Counterinsurgency, ca. 1945-1960 // Comparative studies in Society and History. 2020. Volume 62. Issue 4. P. 684 - 713.

3 Notice of an Original Letter of King James II to Macdonell of Keppoch, after the Battle of Killiecrankie; three letters of General Monck; also, some documents relating to Rob Roy Macgregor, and to Simon, Lord Lovat / Ed. by J.A. Smith // Proceedings of the Society of Antiquaries of Scotland. 1866 - 1868. Vol. 7. P. 249 - 250; To Our Right Trusty and Well-Beloved Cosen and Councellor Johne Lord Viscounte of Dandee. Dublin Castle, March 29, 1689 // Letters of John Grahame of Claverhouse, viscount of Dundee, with illustrative documents. Edinburgh, 1826. P. 36.

${ }^{4}$ The 6th Statute of the Statutes of Icolmkil (Iona), 1609 // Donald J. Gaelic in Scotland 1698-1981. Edinburgh, 1983.

5 Примечательный факт: возмущение, вызванное в Шотландии истреблением МакДоналдов из Гленко, избранных правительством Вильгельма III Оранского для наказания в назидание нелояльным кланам Горной Страны, монарх вскоре использовал в целях благоприятной презентации собственной персоны в «Северной Британии», организовав «расследование» произошедших в начале февраля 1692 г. событий (Warrant to Commission for Inquiring into the Slaughter of the M'donalds of Glencoe, April 1695. Proceedings of the Society of Antiquaries of Scotland. 1862 - 1864. V. 5. P. 59 - 60); Campbell J., 1st Earl of Bredalbane. List of Chieftains named in the Scheme proposed to the king for utilizing the Highlanders in case of any insurrection at home, or invasion from abroad, 1692 // Keltie J.S. History of the Scottish Highlands, Highland Clans and Highland Regiments. With an Account of the Gaelic Language, Literature, and Music by $\mathrm{T}$. Maclauchlan and an Assay on Highland Scenery by 
J. Wilson. Vol. I - II. Edinburgh and London, 1875. P. 404 - 405.

${ }^{6}$ Chambers $R$. Domestic Annals of Scotland. From the Revolution to the Rebellion of 1745 . Vol. III. Edinburgh and London, 1874. P. 252 - 254.

${ }^{7}$ Robbins K. Religion and Identity in Modern British History // Religion and National Identity. Oxford, 1982. P. 482.

${ }^{8}$ MacLean W.L. Religion in the Clachan // Home Life of the Highlanders 1400-1746. Glasgow, 1911.

${ }^{9}$ MacDonald R.C. Moidart: Among the Clanranalds. Edinburgh, 1997. P. 235.

${ }^{10}$ Cunningham A.D. History of Rannoch. Inverness, 1994; Graham N. An Inquiry into the Causes which facilitate the Rise and Progress of Rebellions and Insurrections in the Highlands of Scotland, 1747 // Burt E. Letters from a Gentleman in the North of Scotland to His Friend in London. With large Appendix, containing various important historical documents, hitherto unpublished; with an introduction and notes by R. Jamieson. Vol. II /
Ed. by R. Jamieson. Edinburgh, Glasgow, London, 1822. P. 339.

${ }^{11}$ Chambers R. Op. cit. P. 254.

${ }^{12}$ Neilson $R$. Report on conditions in Moidart for the Commissioners of Fisheries and Manufacturers, 1755 // National Library of Scotland. MS. La. 11.623.

${ }^{13}$ MacDonald R.C. Op. cit. P. 146.

${ }^{14}$ В абсолютном выражении: 75.000 человек из 300.000 населения Горной Шотландии в конце XVIII - начале XIX в.: Davidson N. Scottish Imperialism and National Identity (Part 1) // The first part of the Speech at the Word Power Books Fringe Festival on 15 August 2004.

${ }^{15}$ MacKillop A. The political culture of the Scottish Highlands from Culloden to Waterloo // The Historical Journal of Cambridge. Vol. 46,3. September 2003. P. 514-516.

${ }^{16}$ English Historical Documents. Vol. X. 1714-1783/ Ed. by D.B. Horn, M.A. Ransome and M. Ransome. London, 1957. P. 662 - 664.

\title{
EDUCATIONAL POLICY AND BRITISH IDENTITY FORMATION AT THE NATIONAL OUTSKIRTS
}

\author{
(C) 2021 S.G. Malkin
}

\section{Samara State University of Social Sciences and Education}

Addressing historical cases has not only academic but also political significance, especially if the current agenda is largely determined by the rhetoric and experience of conflicts rooted in history. In this regard, the article focuses on the nature, forms and consequences of British educational policy on the national outskirts in Modern times in the formation of British identity, which supported the practice of national and state building at the ideological level both within the United Kingdom and within the British Empire. Specific historical and contemporary examples demonstrate the possibilities and limitations of educational policy as a humanitarian technology for strengthening the ideological and rhetorical foundations of Great Britain as a multinational and complex public entity. The study focuses on the Scottish case which has the deepest historically roots; its analysis allows a more detailed study of the relationship between the educational strategies of the authorities in the past and their consequences in the present, taking into account the prospects for a second referendum on Scottish independence in the context of Britain's exit from the European Union.

Keywords: educational policy; British identity; national outskirts; Great Britain; Ireland; Scotland.

DOI: 10.37313/2658-4816-2021-3-4-66-71

Stanislav Malkin, Doctor of History, Head of the Department of World History, Law and Methods of Education.E-mail:s.g.malkin@mail.ru 